\title{
Original paper \\ Kinematics of the Sirjan mylonite nappe, Zagros Orogenic Belt: insights from strain and vorticity analyses
}

\author{
Khalil SARKARINEJAD, Saeede KESHAVARZ*, Ali FAGHIH \\ Department of Earth Sciences, College of Sciences, Shiraz University, Shiraz, P. O. Box: 71454, Iran; s.keshavarz2007@yahoo.com \\ * Corresponding author
}

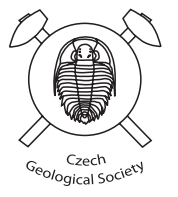

The Sirjan mylonite nappe is part of the HP-LT Sanandaj-Sirjan Metamorphic Belt (Zagros Orogenic Belt, Iran). This nappe was emplaced in a transpressional regime during oblique convergence between the Afro-Arabian Continent and Central Iranian Microcontinent. In order to investigate the type of flow, fabrics from deformed quartz and K-feldspar porphyroclasts were analyzed. Quantitative finite strain $\left(\mathrm{R}_{\mathrm{xz}}=1.9-3.8\right)$ and mean kinematic vorticity number $\left(\mathrm{W}_{\mathrm{m}}=\right.$ $0.60-0.85$ ) analyses revealed that both the strain ratio and the simple shear component of deformation increase towards SE along a $2 \mathrm{~km}$ long NW-SE-oriented transect. Analysis of quartz and K-feldspar textures suggests shearing at c. $400-650^{\circ} \mathrm{C}$. We also conclude that deformation in the Sirjan mylonite nappe began with nearly pure shear flow but became a more simple-shear flow in character as strain accelerated.

Keywords: kinematics, mylonite, vorticity, strain path, deformation, Zagros Orogenic Belt Received: 29 June, 2015; accepted: 23 October, 2015; handling editor: J. Žák

\section{Introduction}

Thrust-related ductile zones of high strain are regions with non-coaxial strain histories localized in planar or curviplanar collision zones (Regenauer-Lieb and Yuen 2003; Vauchez and Tommasi 2003; Williams and Jiang 2005; Xypolias and Kokkalas 2006; Mukherjee 2012; Mukherjee and Biswas 2014). Such high-strain shear zones are encountered commonly in crystalline basement rocks (Ramsay 1980; Passchier et al. 1993) and are useful for geometric and kinematic analyses. These zones, at all scales from sub-microscopic shear bands to zones of intense deformation tens of kilometers wide, occur in the different tectonic settings (White et al. 1980; Passchier et al. 1993; Burg 1999; Carreras 2001; Xypolias et al. 2007). The high-strain zones accommodate significant part of the total deformation in the middle and lower crust and subcrustal lithosphere. The mineral assemblages and geometries of structures within mylonites are good indicators for evaluation of kinematics of these high-strain zones. Some mineral grains such as K-feldspar, quartz, garnet and amphibole in a relatively weaker matrix have received much attention for their kinematic significance. They allow determination of sense of shear or kinematic vorticity number, distinguishing different deformation events, as well as finite strain and deformation temperature (Passchier and Trouw 2005; Iacopini et al. 2008; Hamimi et al. 2014; Mukherjee 2011, 2013, 2014, 2015; Samani 2013; Faghih and Soleimani 2015).

Kinematic and strain components of movement and emplacement in a thrust sheet or nappe are controlled by various mechanisms such as gravitational gliding (requires sliding of the thrust sheet over a generally down-dipping basal slope) or gravitational spreading (horizontal spreading and vertical shortening of a pile of nappes under their own weight) (Jeffreys 1929; Wunderlich 1953; Bucher 1956; van Bemmelen 1960; Kehle 1970; Price and Mountjoy 1970; Price 1973; Ramberg 1980; Rey 2001; Prokešová et al. 2012).

This study focuses mainly on the description and analyses of quartz and $\mathrm{K}$-feldspar porphyroclasts along a c. $2 \mathrm{~km}$ long NE-SW transect across the Sirjan mylonite nappe, Iran. These data provide new kinematic constraints on the shear zone development associated with exhumation of medium- to high-grade metamorphic rocks in the HP-LT Sanadaj-Sirjan Metamorphic Belt. This belt is characterized by ductile transpressional deformation (Mohajjel and Fergusson 2000; Sarkarinejad and Azizi 2008; Sarkarinejad et al. 2008, 2014), which accommodated deformation and displacement of metamorphic rocks during oblique collision between the Afro-Arabian Continent and the Central Iranian Microcontinent (Alavi 2004).

\section{Tectonic framework}

The Zagros Orogenic Belt extends for more than 2000 $\mathrm{km}$ from the East Anatolian Fault of eastern Turkey to the Oman Line in southern Iran (Alavi 1994, 2004). This curvilinear orogenic belt resulted from closure of the Neo-Tethys Ocean and subsequent Late Cretaceous continental collision between the Afro-Arabian Continent and 


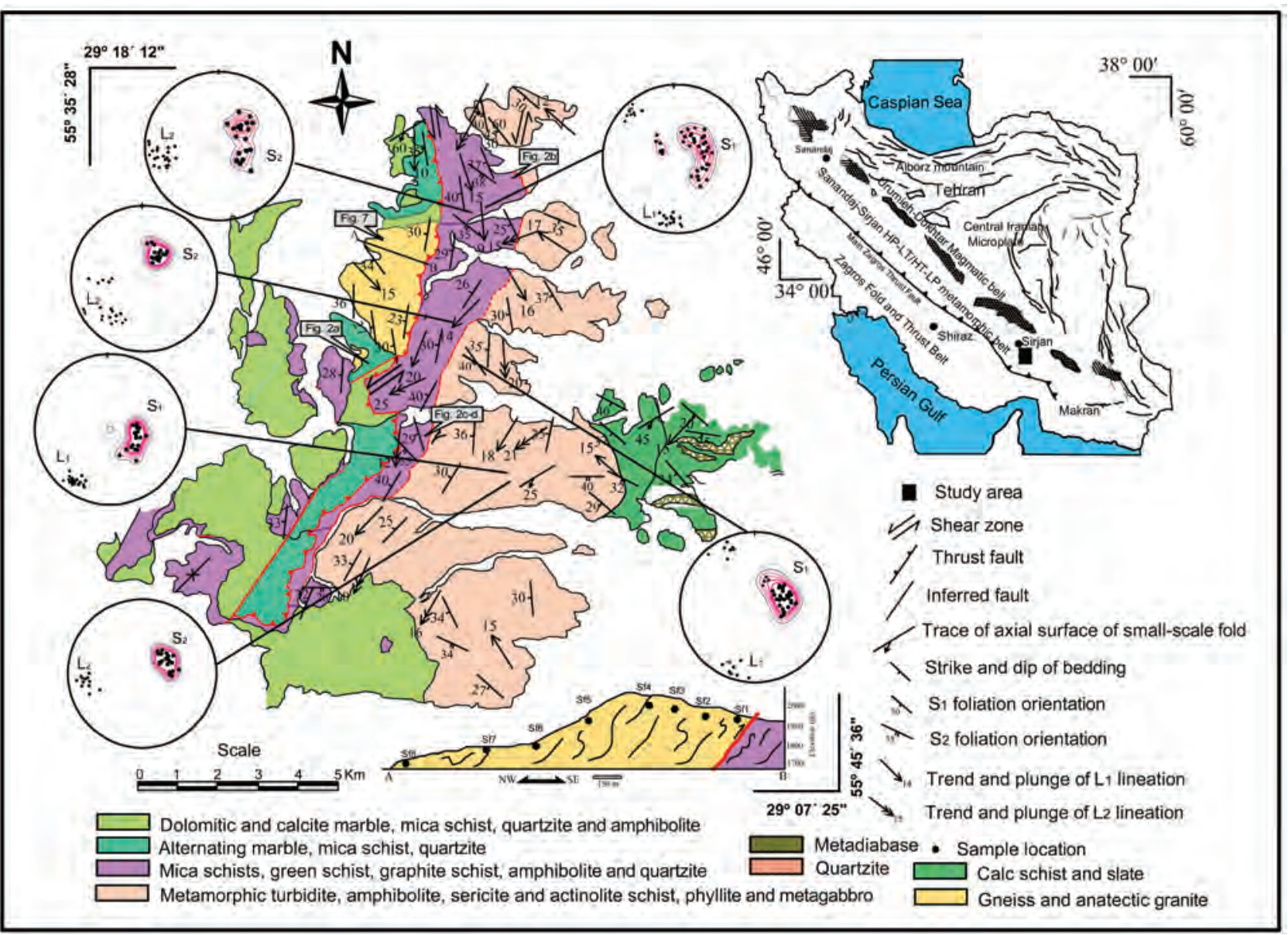

Fig. 1 Schematic map showing main tectonic features of Iran. The study area (black box in inset) is located within the Sanandaj-Sirjan Metamorphic Belt, between the Zagros Fold and Thrust Fault and Urumieh-Dokhtar Magmatic Belt. Detailed structural and geological map of the study area. Locations of samples used for petrofabric measurements and vorticity analyses are shown in cross-section A-B.

Central Iranian Microcontinent (Stöcklin 1968; Berberian and King 1981; Alavi 1994; Blanc et al. 2003; McQuarrie et al. 2003; Sarkarinejad et al. 2008; Sheikholeslami et al. 2008; Agard et al. 2011; Faghih and Sarkarinejad 2011; Mouthereau 2011). From NE to SW, the Zagros region can be divided into three principal tectonic units (Alavi 1994) (Fig. 1): (1) The Urumieh-Dokhtar Magmatic Belt (2) The Sanandaj-Sirjan HP/LT-HT/LT Metamorphic Belt, and (3) The Zagros Fold and Thrust Belt.

The Sanandaj-Sirjan Metamorphic Belt, 150-200 km wide and over $1500 \mathrm{~km}$ long, extends from NW (Sanandaj) to SE (Sirjan) in southeastern Iran (Fig. 1). The belt has been subdivided into southwesterly HP/LT and northeasterly LP/HT domains (Sarkarinejad 1999). Structure of this metamorphic belt is dominated by numerous forethrusts transporting rocks towards SW in a piggyback style (Alavi 1994; Mohajjel and Fergusson 2000).

The study area, located $25 \mathrm{~km}$ south of Sirjan city, is a basement window (Sirjan Window) in the HP-LT domain (Fig. 1). The Sirjan basement window consists of up to several hundred meters thick package of gneissic rocks with a NNE-trending foliation. These rocks structurally overlay the Sirjan thrust sheet. The metamorphic grade decreases from top to bottom as the Sirjan thrust sheet separates gneissic rocks in the hanging wall from a complex of lower grade metamorphic rocks in the footwall. The thrust plane is sub-parallel to the mean foliation in both hanging wall and footwall blocks. Strike of the thrust plane varies from about 170 to $190^{\circ}$ with an average dip of about $20^{\circ}$ to the WNW (Fig. 1). The footwall block comprises deformed greenschists, calc-silicate schists, slates, phyllites, graphite schists and quartzites. These metamorphosed rocks display two generations of subhorizontal stretching lineations defined by long axes of sheared quartz ribbons and amphibole aggregates: $\mathrm{L}_{1}$ lineation plunges to the $\sim \mathrm{S}$ to $\sim \mathrm{SSW}$ and $\mathrm{L}_{2}$ lineation plunges to the $\sim$ WSW (Fig. 1). Footwall rocks also show pervasive S/C fabrics and asymmetric boudins that reveal top-to-the SW sense of shear (Fig. 2a-b).

The gneisses are variably mylonitized from protomylonitic augen gneiss through mylonitic orthogneiss to ultramylonite. The main mineral assemblage of these rocks is quartz $+\mathrm{K}$-feldspar + plagioclase + biotite + muscovite + amphibole and indicates greenschist- to amphibolites-facies 

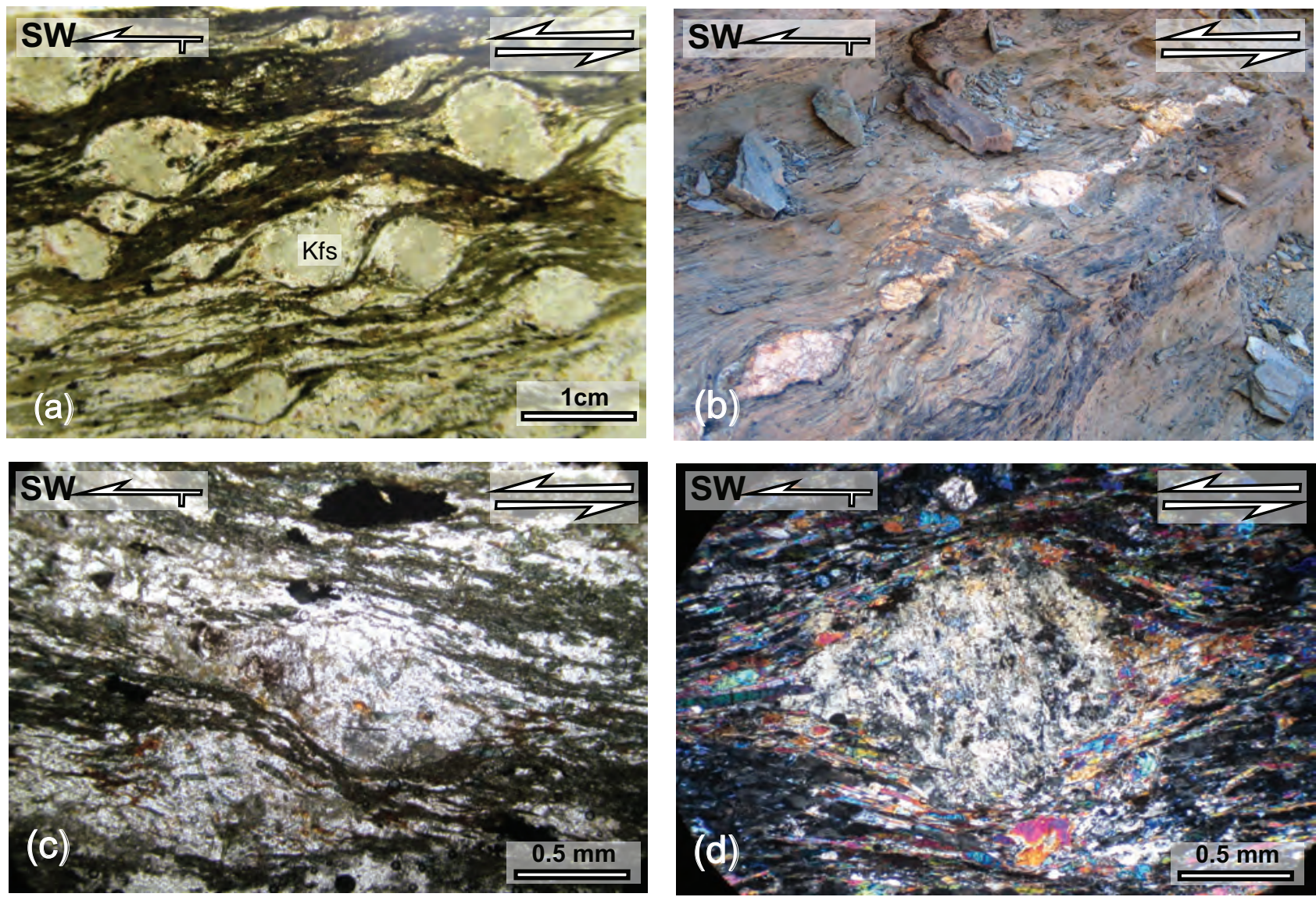

Fig. 2 Photographs of Sirjan mylonite samples illustrating meso- and micro-scale deformation structures. a - An augen gneiss/sheared mylonite with rotated K-feldspar porphyroclasts and S/C-type shear bands. Some porphyroclasts in this photo show reverse shear sense. Likewise, Mukherjee and Koyi (2010) found reverse ductile shear senses from thin sections of their Himalayan samples. $\mathbf{b}$ - Asymmetric train of shear-band boudins (Goscombe et al. 2004) of quartz veins oriented sub-parallel to mylonitic foliation in the Sirjan shear zone. c - Photomicrograph of $\sigma$-type alkalifeldspar porphyroclast. d - Photomicrograph of $\delta$-type quartz porphyroclast with muscovite wings. All photos are perpendicular to foliation and parallel to stretching lineation and show top-to-the-SW sense of shear.

conditions during mylonitization. Penetrative foliation is defined by alignment of mica grains and stretched quartz and $\mathrm{K}$-feldspar grains. The orientation of the main foliation varies from $198^{\circ}, 25^{\circ} \mathrm{NW}$ to $165,30^{\circ} \mathrm{SW}$. This foliation is overprinted by an asymmetrical crenulation cleavage, commonly oriented at $c .30^{\circ}$ to the main foliation. The $\sigma$-type and $\delta$-type $\mathrm{K}$-feldspar porphyroclasts in a fine-grained matrix indicate top-to-the-SW sense of shear (Fig. 2c-d).

\section{Finite strain analysis}

Finite strain ratios $\left(\mathrm{R}_{\mathrm{XZ}}, \mathrm{R}_{\mathrm{XY}}\right.$ and $\left.\mathrm{R}_{\mathrm{YZ}}\right)$ were estimated using the $\mathrm{R}_{\mathrm{f}} / \Phi$ method (Dunnet 1969; Ramsay and Huber 1983; Lisle 1985) from rotated K-feldspar porphyroclasts in oriented thin sections (Klepeis et al. 1999; Poli and Oliver 2001; Xypolias et al. 2010; Kassem 2014). The sections were cut parallel to the foliation (XY plane of strain), normal to the foliation and parallel to the lineation (XZ plane of strain) and normal to the foliation and lineation (YZ plane of strain). In each section, aspect ratios (a/b) were determined from the longest (a) and shortest (b) axes of the porphyroclasts. The angle $\Phi$ was measured between the long axes of porphyroclasts and the inferred principal extension direction as a reference line for each thin section (Fig. 2a). It seems that the principal extension direction is subparallel to the C-plane in $\mathrm{S}-\mathrm{C}$ mylonites. At least 50 rotated porphyroclasts of $\sigma$ and $\delta$ types were measured in each thin section. By using the $\mathrm{Rf} / \Phi$ software (Chew 2003), the $\mathrm{R}_{\mathrm{f}} / \Phi$ diagrams were constructed (Fig. 3) and compared to the standard 'onion curves' in which the $\theta$-distribution test $\left(\chi^{2}\right)$ was used to find the best-fitting $\mathrm{R}_{\mathrm{s}}$ curve (Lisle 1985). In addition, the symmetry was used as a test of the initial random orientation. The data are presented in Tab. 1.

Assuming a constant-volume deformation, the 3D strain was determined by combining 2D data from the inferred $\mathrm{R}_{\mathrm{XY}}$ and $\mathrm{R}_{\mathrm{YZ}}$ principal planes of the strain ellipsoid (Ramsay and Huber 1983). The dominant crystal-plastic deformation indicated by the subgrain-rotation-recrystallization microstructure (Hirth and Tullis 1992) and no microstructural evidence for solution transfer both 

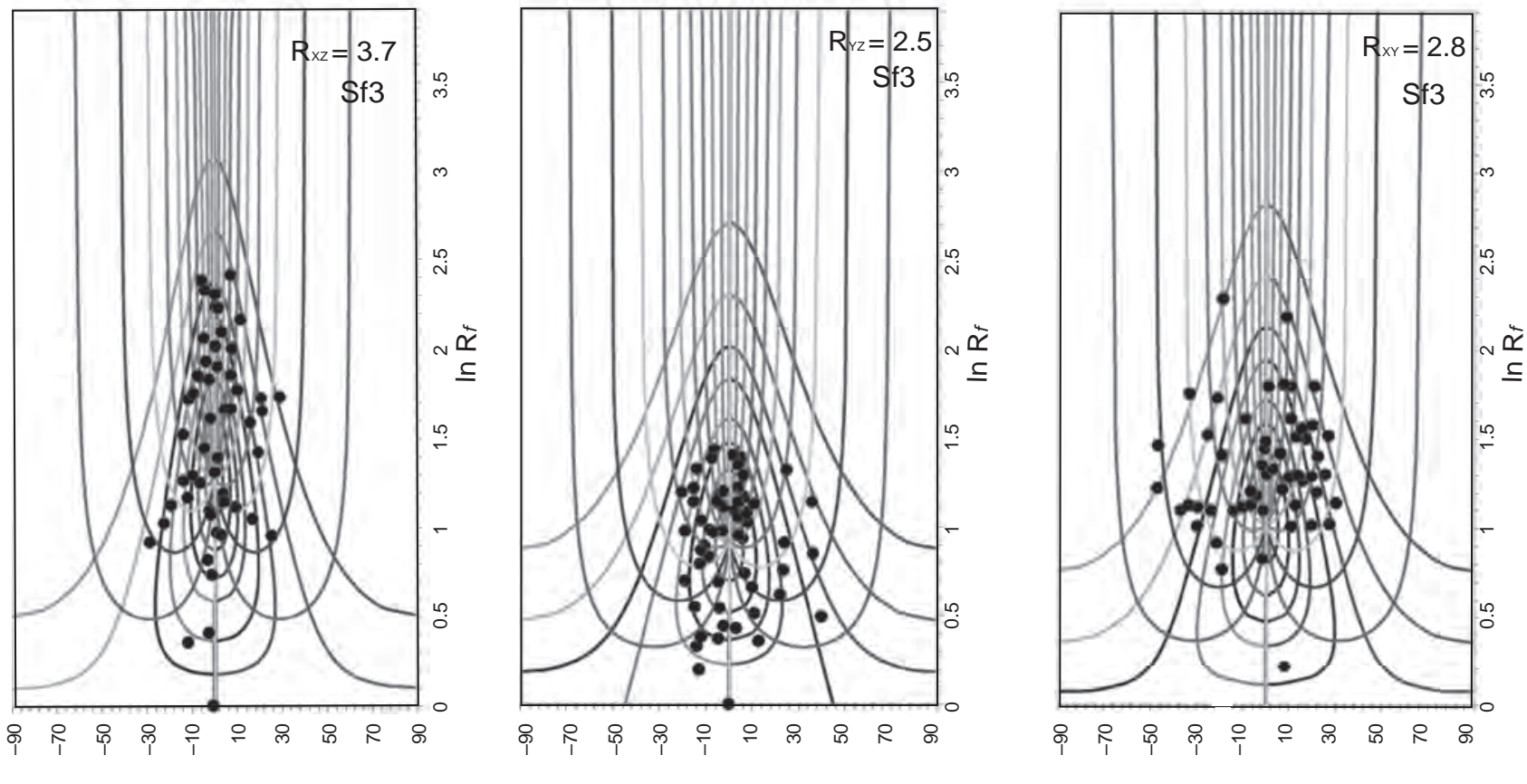

Fig. 3 Estimation of $\mathrm{R}_{\mathrm{s}}$ finite strain parameters by the $\mathrm{R}_{\mathrm{f}} / \Phi$ method for the representative samples of Sf3.

indicate approximate constant-volume deformation (e.g. Sullivan 2008). Principal axes of the strain ellipsoid (X $\geq Y \geq Z$ ), strain ellipsoid shape (k) and Nádai octahedral shear strain $\left(\varepsilon_{\mathrm{s}}\right)$ have been estimated using the Strain and Shear Calculator 3.2 program (Holcombe 2015).

In the Sirjan mylonite nappe (Fig. 4a), the finite strain data plot in both the apparent flattening and constrictional fields but they generally lie close to the plane-strain line (average $\mathrm{k}=1.05$ ). Moreover, samples from the gneissic rocks show strain magnitude expressed by the Nádai octahedral shear strain $\left(\varepsilon_{s}\right)$ ranging from 0.70 to 1.67 (Tab. 2).

\section{Finite strain profiles}

The results of strain analysis are plotted in Fig. 4b. The graph illustrates the variation in $\mathrm{R}_{\mathrm{xz}}$ (strain ratio in XZplane) values versus distance above the thrust plane. The strain magnitude increases nonlinearly (possibly negatively exponentially) towards the lower structural levels of the gneissic rocks. In detail, the $\mathrm{R}_{\mathrm{xz}}$ values decrease from 3.8 near the basal thrust to $\sim 1.9$ at a projected vertical distance of $497 \mathrm{~m}$ above it.

\section{Vorticity analysis}

The kinematic vorticity number $\left(\mathrm{W}_{\mathrm{k}}\right)$ is defined as the ratio of pure and simple shear deformation, ranging from zero to one for pure and simple shearing, respectively (Means 1994). The terms sub-simple shear or general shear are used for intermediate cases between these end-member deformation regimes (Passchier and Trouw 2005). The spatial and temporal variations of vorticity in rocks can be estimated by using a time-averaged (assuming steady-state deformation history), mean kinematic vorticity number

Tab. 1 Finite strain data $\left(\mathrm{R}_{\mathrm{s}}\right)$ using the $\mathrm{R}_{\mathrm{f}} / \varphi$ method with index of symmetry test $\left(\mathrm{I}_{\mathrm{SYM}}\right)$ and $\theta$-distribution test $\left(\mathrm{c}^{2}\right)$.

\begin{tabular}{|c|c|c|c|c|c|c|c|c|c|}
\hline \multirow[b]{2}{*}{ Sample } & \multicolumn{3}{|c|}{$\mathrm{XY}$} & \multicolumn{3}{|c|}{$\mathrm{XZ}$} & \multicolumn{3}{|c|}{$\mathrm{YZ}$} \\
\hline & $\mathrm{R}_{\mathrm{s}}$ & $\mathrm{I}_{\text {sym }}{ }^{\dagger}$ & $\mathrm{C}^{2 \ddagger}$ & $\mathrm{R}_{\mathrm{s}}$ & $\mathrm{I}_{\text {sym }}$ & $\mathrm{c}^{2}$ & $\mathrm{R}_{\mathrm{s}}$ & $\mathrm{I}_{\text {sym }}$ & $\mathrm{c}^{2}$ \\
\hline Sf1 & 3.40 & 0.98 & 03.00 & 3.80 & 0.91 & 8.34 & 3.15 & 0.93 & 3.50 \\
\hline Sf2 & 2.90 & 0.90 & 13.00 & 3.45 & 0.82 & 2.41 & 3.00 & 0.87 & 4.51 \\
\hline Sf3 & 2.80 & 0.80 & 11.17 & 3.70 & 0.82 & 1.99 & 2.50 & 0.86 & 6.80 \\
\hline Sf4 & 2.40 & 0.96 & 6.14 & 3.15 & 0.90 & 8.43 & 2.00 & 0.98 & 4.80 \\
\hline Sf5 & 2.30 & 0.97 & 11.30 & 2.90 & 0.80 & 14.00 & 2.10 & 0.81 & 5.16 \\
\hline Sf6 & 1.30 & 0.87 & 13.90 & 2.40 & 0.96 & 9.60 & 1.45 & 0.83 & 5.38 \\
\hline Sf7 & 1.65 & 0.89 & 4.41 & 2.00 & 0.97 & 10.83 & 1.75 & 0.86 & 3.77 \\
\hline Sf8 & 1.80 & 0.98 & 2.83 & 1.90 & 0.98 & 4.92 & 1.70 & 0.95 & 8.52 \\
\hline
\end{tabular}

${ }^{\dagger}$ High value of $\mathrm{I}_{\mathrm{SYM}}$ suggests that the data are symmetrical

${ }^{\ddagger}$ Low value of $c^{2}$ indicates that the initial distribution of marker orientation $(\theta)$ is random (Lisle 1985) 
(a)

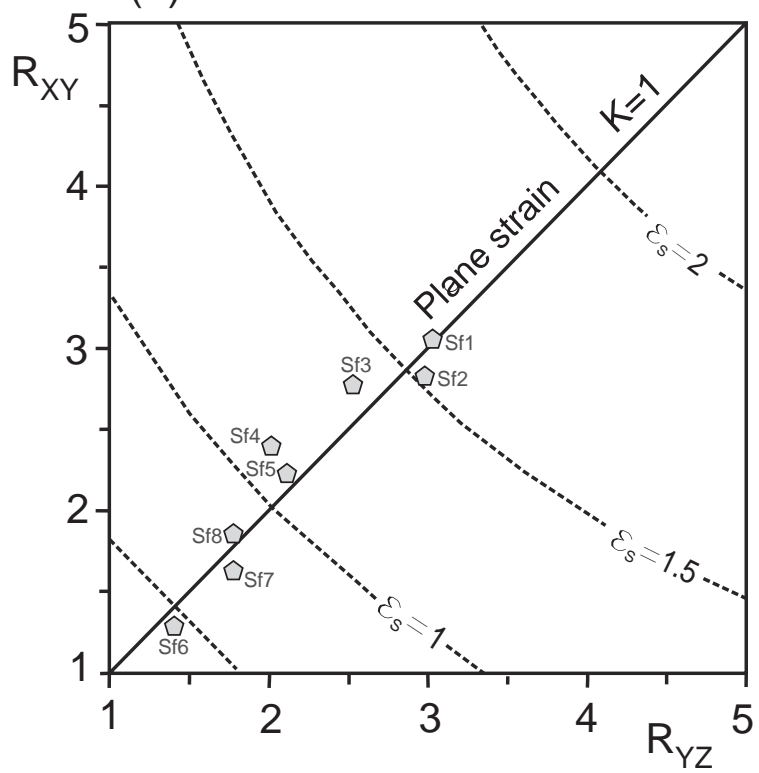

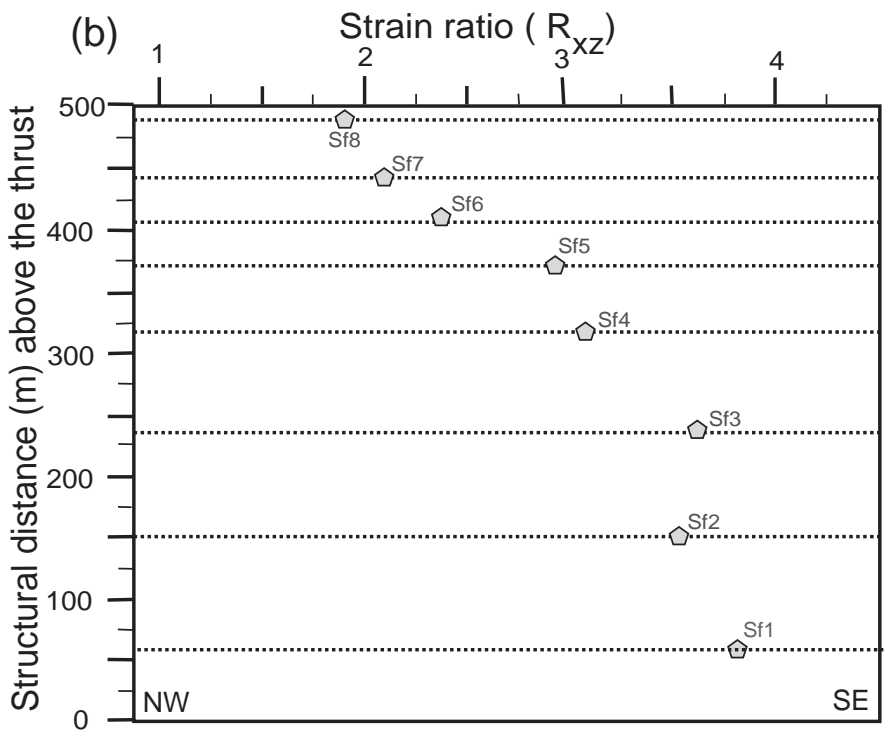

Fig. 4a Flinn diagrams from the Sirjan mylonite nappe. Octahedral shear strain, $\varepsilon_{\mathrm{s}}$ contours for finite strain data are also shown. $\mathbf{b}-$ Graph illustrating the variation in $\mathrm{R}_{\mathrm{xz}}$ (strain ratio in $\mathrm{XZ}$ section) values versus distance above the Sirjan Thrust.

$\left(\mathrm{W}_{\mathrm{m}}\right)$. Determination of $\mathrm{W}_{\mathrm{m}}$ requires that deformation was mainly by plane strain. Numerous techniques and fabric types for quantitative analysis of vorticity in naturally deformed rocks have been proposed (Passchier and Trouw 2005). Among these, several studies (e.g. Ghosh and Ramberg 1976; Passchier 1987; Simpson and De Paor 1993; Masuda et al. 1995; Marques and Coelho 2003; Marques et al. 2007; Kurz and Northrup 2008; Sarkarinejad and Azizi 2008; Langille et al. 2010; Thigpen et al. 2010) argued that vorticity of flow can affect the rotation of rigid porphyroclasts embedded in a deforming ductile matrix. In order to constrain the distribution of coaxial and non-coaxial shear components of deformation, two analytical approaches were applied here: the rigid-grain and the quartz grain shape foliation methods.

\subsection{Rigid-grain method}

The rigid-grain method (Passchier 1987; Wallis et al. 1993; Jessup et al. 2007) was applied to hand specimens and thin sections cut perpendicular to the foliation and parallel to the lineation (XZ-plane). The porphyroclast aspect ratio method (Passchier 1987) uses a population of asymmetric tailed porphyroclasts with varying aspect ratios $(\mathrm{R}=$ long axis/short axis). This method records graphically the rotational behavior of porphyroclasts in the $\mathrm{XZ}$ plane by plotting a sectional clast shape factor $B\left(=\left(R^{2}-1\right) /\left(R^{2}+1\right)\right.$ against the angle $\varphi$ between the long axis of clast and the flow plane (Passchier 1987). For high-strain mylonite, the straight tails of porphyroclasts are considered to be parallel to the flow plane (= C-plane/main foliation/mylonitic foliation). In most published studies the trace of mesoscopic foliation has been taken as the reference line.

Jessup et al. (2007) proposed a new graphical technique, the Rigid Grain Net (RGN), which unifies the rigid grain vorticity methods. The vertical parts of the positive and negative semihyperbolae of the RGN are used to determine the critical shape value $\left(\mathrm{B}_{\mathrm{c}}^{*}\right)$, which separates grains that reached a stable orientation from those that rotated freely. The $\mathrm{W}_{\mathrm{m}}$ value can be determined directly from $\mathrm{B}_{\mathrm{c}}{ }^{*}$

Tab. 2 Strain, microstructural and vorticity data for samples from the Sirjan mylonite nappe

\begin{tabular}{|c|c|c|c|c|c|c|c|c|c|c|}
\hline \multirow{2}{*}{ Sample } & \multicolumn{6}{|c|}{ Strain Parameter } & \multirow{2}{*}{$\beta(\operatorname{deg})$} & \multirow{2}{*}{$\delta(\operatorname{deg})$} & \multicolumn{2}{|c|}{ Vorticity Analysis $\left(\mathrm{W}_{\mathrm{m}}\right)$} \\
\hline & $\mathrm{R}_{\mathrm{xy}}$ & $\mathrm{R}_{\mathrm{xz}}$ & $\mathrm{R}_{\mathrm{yz}}$ & $\mathrm{X}: \mathrm{Y}: \mathrm{Z}$ & $\mathrm{k}$ & $\varepsilon_{\mathrm{S}}$ & & & Method 1 & Method 2 \\
\hline Sf1 & 3.40 & 3.8 & 3.15 & 3.31:0.97:0.31 & 1.12 & 1.67 & - & - & $0.72-0.80$ & - \\
\hline Sf2 & 2.90 & 3.45 & 3,00 & 2.93:1.10:0.34 & 0.95 & 1.53 & $12-16$ & 20 & $0.58-0.60$ & $0.89-0.95$ \\
\hline Sf3 & 2.80 & 3.70 & 2.50 & 2.70:0.96:0.39 & 1.20 & 1.37 & $11-16$ & 13 & $0.65-0.75$ & $0.74-0.84$ \\
\hline Sf4 & 2.40 & 3.15 & 2.00 & $2.26: 0.94: 0.47$ & 1.40 & 1.11 & - & - & $0.58-0.67$ & - \\
\hline Sf5 & 2.30 & 2.90 & 2.10 & 2.23:0.97:0.46 & 1.18 & 1.12 & $13-17$ & 9 & $0.60-0.65$ & $0.70-0.78$ \\
\hline Sf6 & 1.30 & 2.40 & 1.45 & $1.35: 1.04: 0.72$ & 0.67 & 0.45 & - & - & $0.47-0.54$ & - \\
\hline Sf7 & 1.65 & 2.00 & 1.75 & $1.68: 1.02: 0.58$ & 0.87 & 0.75 & - & - & $0.42-0.58$ & - \\
\hline Sf8 & 1.80 & 1.90 & 1.70 & 1.77:0.98:0.58 & 1.07 & 0.70 & - & - & $0.43-0.49$ & - \\
\hline
\end{tabular}



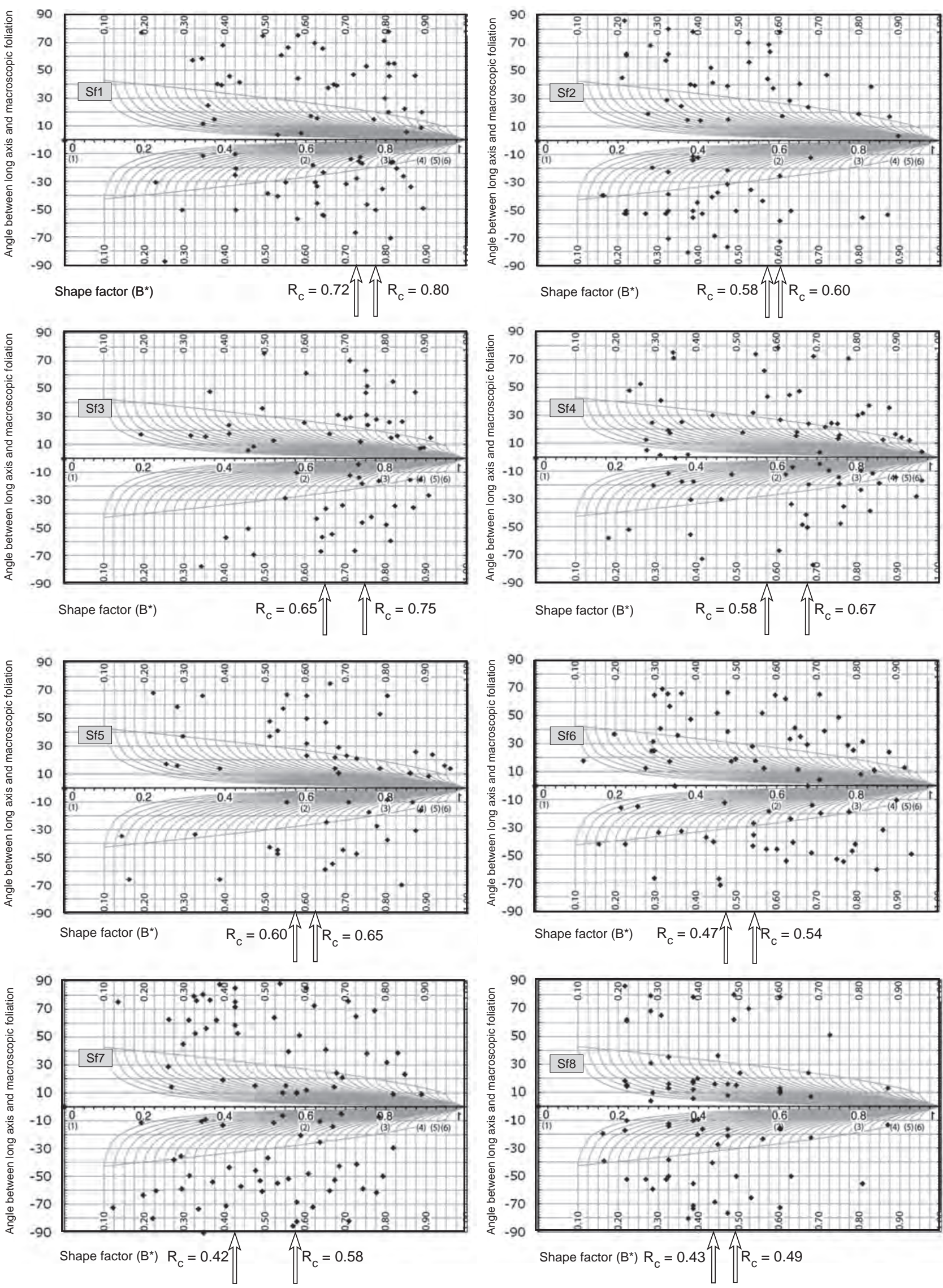
(a)

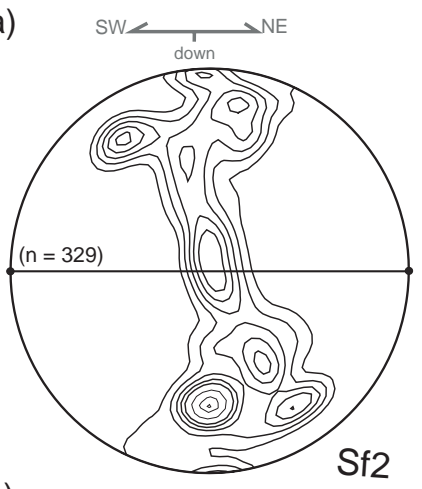

(b)

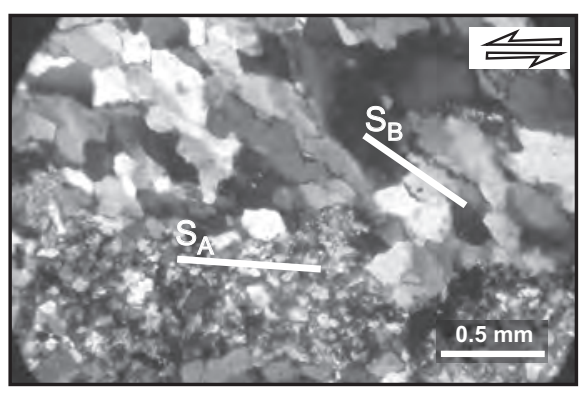

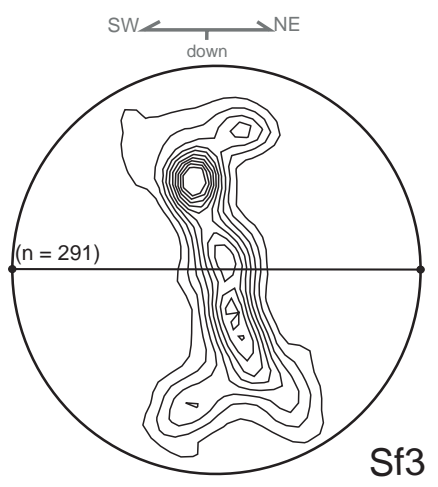

$\mathrm{Sf3}$

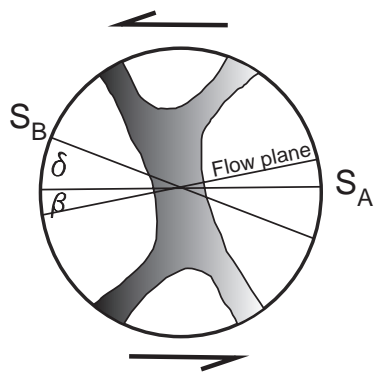

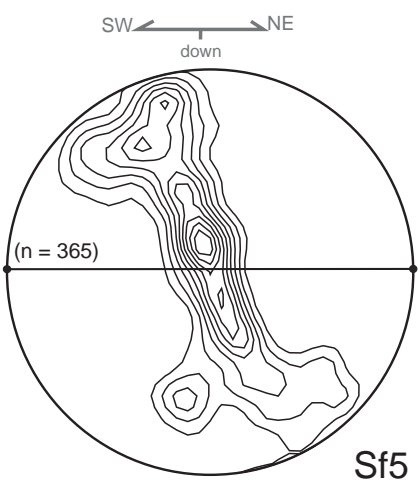

$W_{k}=\sin 2(\delta+\beta)$

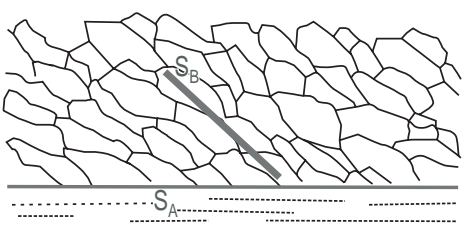

(c)
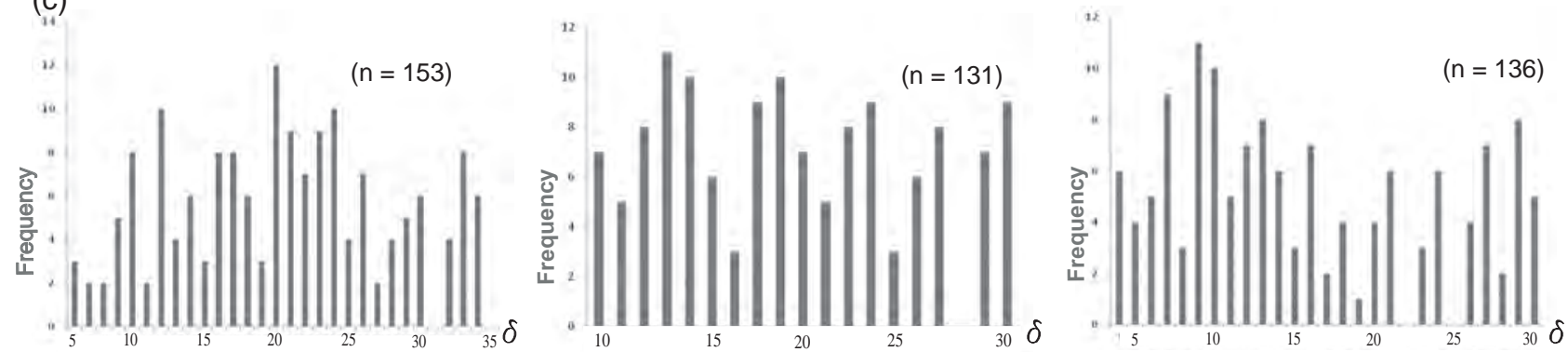

Fig. 6a - Optically measured quartz c-axis fabrics of the three selected quartz-rich samples. Equal area, lower hemisphere stereographic projections; foliation is orientated left-right and vertical; lineation is horizontal; Contour intervals: 2, 4, 6 and 8 times uniform distribution. $\mathrm{n}=$ number of grains measured in each sample. $\mathbf{b}$ - Geometric relationships used in method II vorticity analyses: Schematic diagram demonstrating the relationship between the main foliation $\left(\mathrm{S}_{\mathrm{A}}\right)$, the quartz grain shape foliation $\left(\mathrm{S}_{\mathrm{B}}\right)$, the flow plane, and the quartz [c] axis LPO (Wallis et al. 1993; Law et al. 2004). $\delta$ : angle between the main foliation $\left(\mathrm{S}_{\mathrm{A}}\right)$ and the oblique grain-shape foliation $\left(\mathrm{S}_{\mathrm{B}}\right) ; \beta$ : angle between the central girdle of quartz c-axis fabrics and the main foliation. See text for details. $\mathbf{c}$ - Frequency diagrams used for vorticity $\left(\mathrm{W}_{\mathrm{m}}\right)$ estimates by the quartz grain shape foliation method. $\mathrm{n}=$ number of analyses.

because $\mathrm{B}_{\mathrm{c}}{ }^{*}$ and $\mathrm{W}_{\mathrm{m}}$ are equal (Jessup et al. 2007). The RGN technique was applied to nine of samples containing a sufficient number of K-feldspar porphyroclasts (Fig. 5) which yielded $\mathrm{W}_{\mathrm{m}}$ values ranging from 0.43 to 0.80 .

\subsection{Quartz grain shape foliation method}

This approach was proposed by Wallis (1995) and is based on the theoretical relationship between vorticity

Fig. 5 Rigid porphyroclast analysis of K-feldspar porphyroclasts from samples of the A-B transect (Fig. 1) to determine $\mathrm{W}_{\mathrm{k}}$. Rigid Grain Net (RGN) plots of clast shape factor B* (refer to text) against the angle between clast long axis and macroscopic foliation. The $R_{c}$ numbers show the cut-off points in each sample and estimate the range of critical $\mathrm{B}$-value $\left(\mathrm{B}_{c}^{*}\right)$. Kinematic vorticity number can be determined directly from $B_{c}{ }^{*}$ because $B_{c}{ }^{*}$ and $W_{m}$ are equal (Jessup et al. 2007). and the orientation of lines of zero instantaneous rotation (the flow apophyses) and instantaneous stretching axes (ISA). In other words, the orientation of elongated dynamically recrystallized quartz grains relative to the flow plane in a given sample can be used to estimate the kinematic vorticity number $\mathrm{W}_{\mathrm{k}}$ (Passchier 1988; Wallis 1995). The orientation of the flow plane is determined by drawing a line perpendicular to the central segment of the cross-girdle c-axis fabric on the XZ fabric diagram (Fig. 6a). The angle between foliation and the inferred flow plane is denoted as $\beta$. The orientation of the ISA is obtained by measuring the orientation of elongate dynamically recrystallized quartz grains in XZ thin section. Then, from the population of measured grains, the maximum angle of obliquity $\left(\delta_{\max }\right)$ between the foliation and the long axes of these grains can be determined. 
Measuring the angles $\beta$ and $\delta$, we can estimate $\mathrm{W}_{\mathrm{k}}$ as $\mathrm{W}_{\mathrm{k}}$ $=\sin 2(\beta+\delta)$ (Wallis 1995; Fig. 6b).

In the Sirjan Mylonite Nappe, quartz grain shape foliation method has proved to be applicable to deformed rocks which are characterized by alignment $\left(S_{B}\right)$ of dynamically recrystallized elongate grains oblique to the main foliation $\left(\mathrm{S}_{\mathrm{A}}\right)$ and by a well-developed central girdle segment of the cross-girdle c-axis fabric. In order to accurately define the ISA, $\delta$ was measured on $c .130$ quartz grains per sample (Fig. 6c). The best estimates of the $\delta$ values are listed in Tab. 2 for each of the three samples. The range of calculated $\mathrm{W}_{\mathrm{m}}$ values reflects the degree of uncertainty in determining the $\beta$ values from the quartz $\mathrm{c}$-axis diagrams (Tab. 2). The obtained $\mathrm{W}_{\mathrm{m}}$ values vary from 0.70 to 0.95 .

\section{Deformation temperature}

Feldspar and quartz are abundant minerals in the gneissic rocks, so deformation microstructures of these minerals play a critical role in estimating the deformation temperature (T) (Fitz Gerald and Stünitz 1993; Lloyd and Freeman 1994; Altenberger and Wilhelm 2000; Hirth et al. 2001; Stipp et al. 2002a, b; Law et al. 2004; Law 2014). In naturally-deformed rocks, brittle fracturing of $\mathrm{K}$-feldspar starts at $\mathrm{T} \sim 400^{\circ} \mathrm{C}$ (Passchier and Trouw 2005). Bulging recrystallization grain boundaries (BLG) of $\mathrm{K}$-feldspar are common at $\mathrm{T} \sim 400-600^{\circ} \mathrm{C}$ (Borges and White 1980; Gapais 1989; Gates and Glover 1989; Tullis and Yund 1992; Simpson 1998; Shigematsu 1999; Tullis 2002). Dislocation climb and recovery in K-feldspar begin at $\mathrm{T} \geq 450^{\circ} \mathrm{C}$, and subgrain rotation recrystallization (SGR) becomes important at $\mathrm{T} \sim 500-550^{\circ} \mathrm{C}$ (Simpson 1985; Gapais 1989; Fitz Gerald and Stünitz 1993; Pryer 1993). Above $600^{\circ} \mathrm{C}$, K-feldspar grains deform by SGR and BLG recrystallization that may involve the growth of myrmekite (Vidal et al. 1980; Olsen and Kohlstedt 1985; Tullis and Yund 1985; Simpson and Wintsch 1989; Pryer 1993; Kruse and Stünitz 1999; Altenberger and Wilhelm 2000).

In addition, ductile deformation of quartz is typically defined either by the dislocation creep regimes (Hirth and Tullis 1992) or by mechanisms operating during recrystallization: bulging recrystallization, subgrainrotation recrystallization, and grain-boundary migration recrystallization (GBM) (Stipp et al. 2002a). Stipp et al. (2002a, b) correlated these three dynamic recrystallization mechanisms to temperatures in nature: BLG is dominant between $\sim 280$ and $400^{\circ} \mathrm{C}$, whereas SGR prevails between 400 and $500^{\circ} \mathrm{C}$, and the transition to GBM occurs at $\sim 500^{\circ} \mathrm{C}$.

Microscopic observations demonstrate that K-feldspar and quartz deformed by dynamic recrystallization in the
Sirjan nappe mylonites. Some K-feldspar porphyroclasts show deformation in the form of patchy undulose extinction or deformation twinning. Especially larger grains have been affected by synthetic and antithetic shear frac-
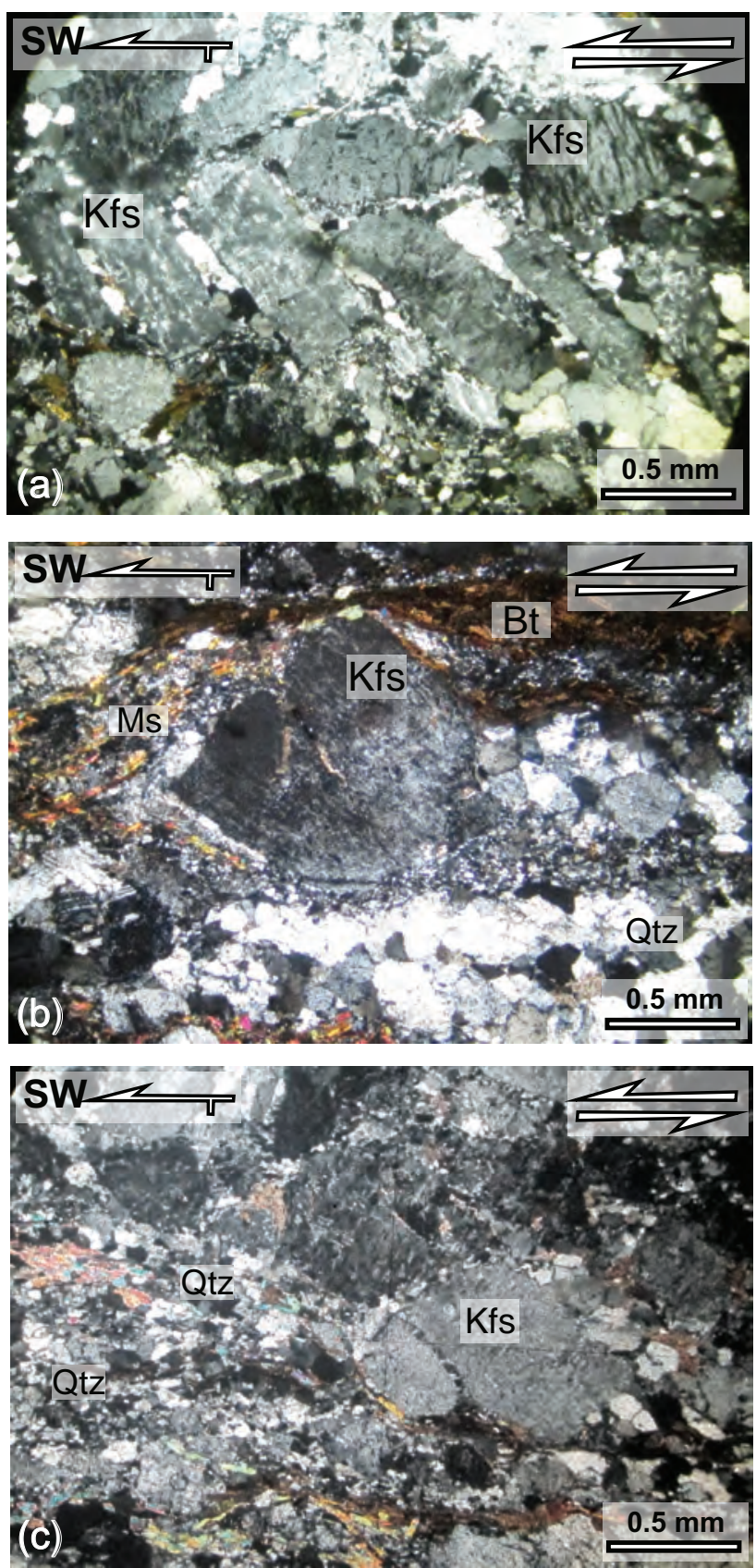

Fig. 7a - Fractured K-feldspar porphyroclast in mylonite indicating top-to-the-SW sense of shear. Grain-boundary migration recrystallization of quartz textures in matrix overprinted by SGR recrystallization. b - Weakly deformed K-feldspar porphyroclast wrapped by a discrete mantle of fine-grained quartz, feldspar and mica. Part of the K-feldspar porphyroclast may show subgrain rotation recrystallisation and bulging into the matrix. Ribbon quartz with grains indicating SGR recrystallization. c - Coexistence of GBM recrystallized quartz and BLG + SGR recrystallized K-feldspar grains, indicating top-to-SW shear sense. Qtz, quartz; Bt, biotite; Ms; muscovite, Kfs; K-feldspar. 
tures (Fig. 7a). Core and mantle structures show bulging and dislocation climb in $\sim 30 \%$ of K-feldspar grains (Fig. $7 b$ ). Retrogressive alteration of K-feldspar to muscovite and quartz is common and was probably associated with the cooling of the Sirjan gneissic rocks. Quartz grains have serrated boundaries and fine grain sizes indicative of GBM recrystalization, while K-feldspar BLG and SGR are widespread in thin-sections (Fig. 7c). In quartz-rich samples, recrystallized grains show oblique grain-shape preferred orientations (Fig. 6b) and confirm the overall top-to-the-SW sense of shear.

\section{Discussion}

We analyzed petrofabric of K-feldspar and quartz-rich samples from the hanging wall of the Sirjan Thrust in order to deduce the flow history of the exhumed gneissic rocks during metamorphic peak. Quantitative finite strain analyses demonstrate that the strain ratio increases structurally downwards the Sirjan Thrust. The structurally higher part of Sirjan thrust sheet is characterized by high strain magnitude associated with plane strain deformation. Deformation in the structurally deeper sections occurred under approximately plane strain conditions and was characterized by a lower strain magnitude (Fig. 4a).

Results of the vorticity analysis of each sample were plotted against structural distance above the basal thrust sheet to examine the spatial variation of $\mathrm{W}_{\mathrm{m}}$ values within deformation zones as well as the consistency of the both methods (Fig. 8). Bars in Fig. 8 reflect the degree of uncertainty in the input data. Our observations indicate that the deformation of rocks in the Sirjan mylonite nappe was characterized by $\mathrm{W}_{\mathrm{m}}$ values $(\sim 0.78)$ that are highest close to the basal thrust sheet and decrease structurally downwards, reaching a value of $\sim 0.46$ at a structural distance of c. $500 \mathrm{~m}$ above the thrust sheet. Given the vorticity profile, comparison between $\mathrm{W}_{\mathrm{m}}$ estimates obtained from methods I and II suggests that method II may overestimate the simple

Fig. 8 Graph illustrating the variation in $\mathrm{W}_{\mathrm{m}}$ values versus structural distance from the Sirjan thrust zone. Length of bars reflects the uncertainty in the calculated $\mathrm{W}_{\mathrm{m}}$ values. For further details, see Tab. 2. shear component close to the thrust sheet (e.g. Langille et al. 2010; Xypolias et al. 2010). It should be noted that if the central part of the quartz c-axis fabric girdle rotates in the shear direction with progressive shearing, as was the case in recent general shear experiments by Heilbronner and Tullis (2006), then results of this method would overestimate $\mathrm{W}_{\mathrm{k}}$. The mean kinematic vorticity number estimates from mylonites in the study area range from 0.46 to $0.76(40-70 \%$ pure shear) using the rigid-grain method $(\mathrm{n}=8)$ and between 0.74 and $0.93(20-30 \%$ pure shear) using the oblique quartz grain shape foliation method $(n=3)$. Vorticity constrained using quartz shape fabrics shows a higher component of simple shear than that estimated using rigid porphyroclasts. Assuming that the quartz is more sensitive to late-stage changes in deformation than the rigid porphyroclasts, $\mathrm{W}_{\mathrm{m}}$ estimates derived from the quartz fabrics can be interpreted as recording the last increments of ductile deformation (Wallis 1995; Xypolias 2009).

The temporal variations of natural flow are, however, difficult to demonstrate from kinematic indicators (Jiang and White 1995; Fossen and Tikoff 1997; Xypolias 2001). Fossen and Tikoff (1997) showed the importance of temporal variations of flow type during deformation and suggested that deformation that undergoes minimum strain path commences close to simple shear but rapidly changes to a more pure shear dominated flow.

Moreover, earlier quantitative field studies from the Main Central Thrust Zone of NW Himalaya (e.g.

\section{Percent pure shear}

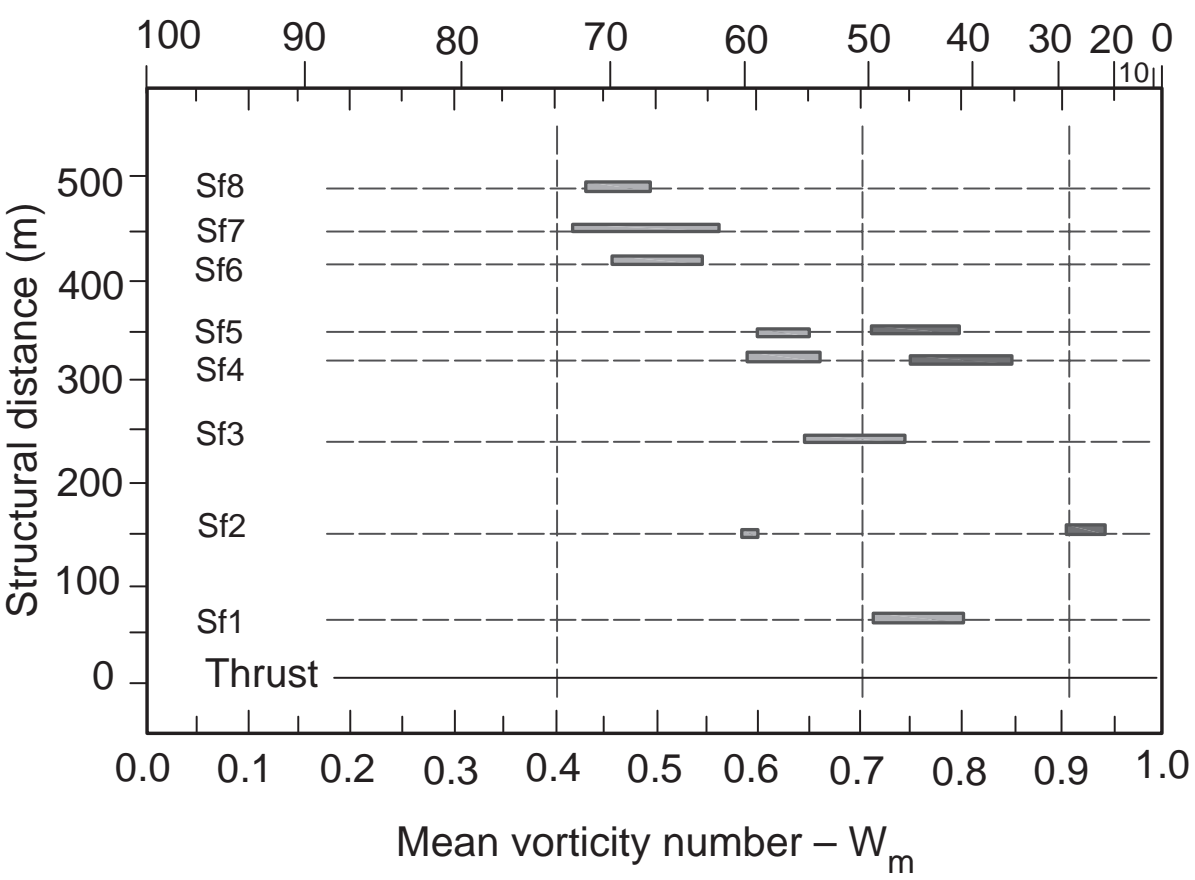

Method 1 - Rigid Porphyroclast

Method 2 - Oblique grain shape \& Quartz c-axis fabrics 
Graseman et al. 1999), the Ochi nappe in the Alpine orogenic belt of Greece (e.g. Xypolias et al. 2010), the Mount Everest Massif of Tibet/Nepal (e.g. Jessup et al. 2006), Sutlej section in Higher Himalayan Shear Zone (e.g. Mukherjee and Koyi 2010) and the Sanbagawa Belt (SW Japan; Wallis 1992, 1995), have shown that in natural shear zones the assumption of decelerating and accelerating strain paths appeared to be valid, at least as a qualitative approach. A decelerating strain path is a special type of deformation path, where the kinematic vorticity number decreases as deformation proceeds. On the other hand, an increase in simple shearing during the final increment of ductile deformation implies an accelerating flow path (Xypolias 2010).

Based on these ideas, we suggest that thrusting exhumation/extrusion (Beaumont et al. 2004) along the Sirjan mylonite nappe may also have involved such a non-steady-state deformation path. Comparison of these strain data with the theoretical curves in Fig. 4a and Tab. 2 confirms that the shear strains increase down to the basal thrust sheet. Spatial variation of strain in combination with the spatial variation of the kinematic vorticity number implies a heterogeneous pattern of deformation in Sirjan mylonite nappe.

K-feldspar in the mylonites of the study area exhibits widespread recrystalization with the BLG or a mixture of BLG and SGR. These recrystalization types indicate deformation temperature of $500-650{ }^{\circ} \mathrm{C}$ (Passchier and Trouw 2005). In addition, within some samples, quartz experienced SGR recrystallization and K-feldspar porphyroclasts deformed by brittle fracturing which indicates deformation temperatures of $400-500^{\circ} \mathrm{C}$ (Fig. 7a). In such samples, quartz GBM recrystallization was overprinted by SGR recrystallization. The rare quartz BLG recrystallization suggests that temperatures were probably in the transitional zone between BLG and SGR. Mylonitization temperatures inferred from quartz microstructure are similar to estimates from K-feldspar recrystallization.

These petrofabric observations suggest that earlier pure shear dominated flow was associated with quartz GBM and K-feldspar SGR recrystallization (rigid-grain method) at higher temperatures and was overprinted by non-coaxial flow (quartz grain shape foliation method) at lower temperatures (Langille et al. 2010). It seems that the rigid-grain method (40-70\% pure shear) records an early part of the exhumation history when deformation was in transition from high-temperature distributed shear located to mylonite (Fig. 8). This was followed by quartz fabrics with $\mathrm{W}_{\mathrm{m}}$ indicating $20-40 \%$ pure shear; we interpret these values as recording a later part of the deformation history when these rocks were exhumed (Fig. 8). The data show a spatial and temporal variation in deformation that progressed from dominantly pure shear to dominantly simple shear deformation during exhumation and cooling from 650 to $400^{\circ} \mathrm{C}$. Assuming a linear, steady-state geothermal gradient of $\sim 30^{\circ} \mathrm{C} / \mathrm{km}$ for the orogenic crust, the Sirjam gneissic nappe may have developed at depths of $\sim 13-21 \mathrm{~km}$. The exhumation of the Sirjan mylonite nappe and the associated spatial and temporal patterns of inferred flow kinematics and deformation temperature are consistent with other high-grade nappes described elsewhere (e.g. Jessupe et al. 2006; Law 2010; Xypolias et al. 2010; Law et al. 2013).

\section{Conclusions}

Detailed microstructural data and kinematic analyses carried out on deformed gneisses of the Sirjan mylonite nappe within Zagros Orogenic Belt suggest that they record deformation under greenschist- to amphibolitesfacies conditions. 3D strain analyses using the $\mathrm{K}$-feldspar porphyroclast populations as strain markers indicate that mylonitic samples lie close to the plane strain path $(k=1)$ on the Flinn diagram. Finite strain ratios and shear strain for the hanging wall are the highest $\left(\mathrm{R}_{\mathrm{xz}}=3.8\right.$ and $\left.\varepsilon_{\mathrm{s}}=1.67\right)$ close the Sirjan Thrust plane. Quantitative kinematic vorticity and microstructural analyses show that deformation within the Sirjan mylonite nappe involved general non-coaxial flow with contemporaneous contributions of pure and simple shear. The relative contributions of simple shear presumably changed with time: the earlier exhumation stage developed during a pure-sheardominated regime whereas the later exhumation stage took place in simple-shear-dominated deformation (i.e. a accelerating strain path). Spatial variation in the deformation path is demonstrated by changes from simple shear to more pure shear components with increasing structural distance from the basal thrust sheet.

Acknowledgements. We would like to thank the chief editor V. Janoušek and both reviewers C. J. Talbot and S. Mukherjee for critical reviews, which helped considerably to improve the scientific content and presentation of the manuscript. Associate Editor Jiř́ Žák is thanked for editorial handling. The Research Council of the Shiraz University, which supported this work, is also gratefully acknowledged.

\section{References}

Agard P, Omrani J, Jolivet L, Whitechurch H, Vrielynck B, Spakman W, Monié P, Meyer B, Wortel R (2011) The Zagros: a subduction-dominated process. In: GRASEMANN B, Simpson G (eds) Geodynamic Evolution of the Zagros. Geol Mag 148: 692-725 
Alavi M (1994) Tectonics of Zagros Orogenic Belt of Iran: new data and interpretation. Tectonophysics 229: 211-238

Alavi M (2004) Regional stratigraphy of the Zagros foldthrust belt of Iran and its proforeland evolution. Amer J Sci 304: 1-20

Altenberger U, Wilhelm S (2000) Ductile deformation of K-feldspar in dry eclogite facies shear zones in the Bergen Arcs, Norway. Tectonophysics 320: 107-121

Beaumont C, Jamieson RA, Nguyen MH, Medvedev S (2004) Crustal channel flows: 1 . Numerical models with applications to the tectonics of the Himalayan-Tibetan Orogen. J Geophys Res 109: doi: 10.1029/2003JB002809

Berberian M, King GCP (1981) Towards a paleogeography and tectonic evolution of Iran. Can J Earth Sci 18: 210-265

Blanc EJP, Allen MB, Inger S, Hassani H (2003) Structural styles in the Zagros simple folded zone, Iran. J Struct Geol 160: 401-412

Borges FS, White SH (1980) Microstructural and chemical studies of sheared anorthosites, Roneval, South Harris. J Struct Geol 2: 273-280

Bucher WH (1956) Role of gravity in orogenesis. Geol Soc Am Bull 67: 1295-1318

BuRG JP (1999) Ductile structures and instabilities: their implications for Variscan tectonics in the Ardennes. Tectonophysics 309: 1-25

Carreras J (2001) Zooming on Northern Cap de Creus shear zones. J Struct Geol 23: 1457-1486

CHew DM (2003) An Excel spreadsheet for finite strain analysis using the $\mathrm{R}_{\mathrm{f}} / \Phi$ technique. Comput and Geosci 29: 795-799

Dunnet D (1969) A technique of finite strain analysis using elliptical particles. Tectonophysics 7: 117-136

FAghin A, SARKARINEJAd K (2011) Kinematics of rock flow and fabric development associated with shear deformation within the Zagros transpression zone, Iran. In: Lacombe O, Grasemann B, Simpson G (eds) Geodynamic Evolution of the Zagros. Geol Mag 148: 1009-1017

Faghin A, Soleimani M (2015) Quartz c-axis fabric development associated with shear deformation along an extensional detachment shear zone: Chapedony Metamorphic Core Complex, Central-East Iranian Microcontinent. J Struct Geol 70: 1-11

Fitz Gerald JD, StüNitz H (1993) Deformation of granitoids at low metamorphic grade I: reactions and grain size reduction. Tectonophysics 221: 269-297

Fossen H, Tikoff B (1997) Forward modeling of nonsteady-state deformations and the 'minimum strain path'. J Struct Geol 19: 987-996

GAPAIS D (1989) Shear structures within deformed granites: mechanical and thermal indicators. Geology 17: 1144-1147
Gates AE, Glover L (1989) Alleghanian tectono-thermal evolution of the dextral transcurrent Hylas Zone, Virginia Piedmont, USA. J Struct Geol 11: 407-419

Ghosh SK, Ramberg H (1976) Reorientation of inclusions by combination of pure shear and simple shear. Tectonophysics 34: 1-70

Goscombe B, Passchier CW, Hand M (2004) Boudinage classification: end member boudin types and modified boudin structures. J Struct Geol 26: 739-763

Grasemann B, Fritz H, Vannay JC (1999) Quantitative kinematic flow analysis from the Main Central Thrust Zone (NW-Himalaya, India): implications for a decelerating strain path and the extrusion of orogenic wedges. J Struct Geol 21: 837-853

Hamimi Z, El-Sawy Kel, El-Fakharani A, Matsah M, ShuJoOn A, El-Shafei M (2014) Neoproterozoic structural evolution of the NE-trending Ad-Damm Shear Zone, Arabian Shield, Saudi Arabia. J Afr Earth Sci 99: 51-63

Heilbronner R, Tullis J (2006) Evolution of c-axis pole figures and grain size during dynamic recrystallization: results from experimentally sheared quartzite. J Geophys Res 111: doi: 10.1029/2005JB004194

HiRTH G, Tullis J (1992) Dislocation creep regimes in quartz aggregates. J Struct Geol 21: 1603-1614

Hirth G, Teyssier C, Dunlap WJ (2001) An evaluation of quartzite flow laws based on comparisons between experimentally and naturally deformed rocks. Int J Earth Sci 90: $77-87$

Holcombe R (2015) Structural Geology - Mapping/GIS Software. Accessed on October 22, 2015, at http://www. holcombe.net.au/software/

Iacopini D, Carosi R, Montomoli C, Passchier CW (2008) Strain analysis and vorticity of flow in the Northern Sardinian Variscan Belt: recognition of a partitioned oblique deformation event. Tectonophysics 446: 77-96

Jefrereys H (1929) Earth, $2^{\text {nd }}$ edn. Cambridge University Press, Cambridge, pp 1-346

Jessup MJ, Law RD, SEarle MP, Hubbard MS (2006) Structural evolution and vorticity of flow during extrusion and exhumation of the Greater Himalayan Slab, Mount Everest Massif, Tibet/Nepal: implications for orogenscale flow partitioning. In: LAw RD, SEARLE MP, Godin L (eds) Channel Flow, Ductile Extrusion and Exhumation in Continental Collision Zones. Geological Society London Special Publications 268: 379-414

Jessup MJ, Law RD, Frassi C (2007) The Rigid Grain Net (RGN): an alternative method for estimating mean kinematic vorticity number $\left(\mathrm{W}_{\mathrm{m}}\right)$. J Struct Geol 29: 411-421

JIANG D, WhITE JC (1995) Kinematics of rock flow and the interpretation of geological structures with particular reference to shear zones. J Struct Geol 17: 1249-1266

Kassem OMK (2014) Kinematic analysis of the Migif area in the Eastern Desert of Egypt. J Struct Geol 99: 136-149 
KeHLE RO (1970) Analysis of gravity sliding and orogenic translation. Geol Soc Am Bull 81: 1641- 1664

Klepeis KA, DaczKo NR, Clarke GL (1999) Kinematic vorticity and tectonic significance of superposed mylonites in a major lower crustal shear zone, northern Fiordland, New Zealand. J Struct Geol 21: 1385-1405

Kruse R, Stünitz H (1999) Deformation mechanisms and phase distribution in mafic high-temperature mylonites from the Jotun Nappe, southern Norway. Tectonophysics 303: 223-249

Kurz GA, Northrup CJ (2008) Structural analysis of mylonitic rocks in the Cougar Creek Complex, OregonIdaho using the porphyroclast hyperbolic distribution method and potential use of SC'-type extensional shear bands as quantitative vorticity indicators. J Struct Geol 30: 1005-1012

Langille J, Jessup MJ, Cottle JM, Newell DL (2010) Kinematics of the Ama Drime Detachment: insights into orogen-parallel extension and exhumation of the Ama Drime Massif, Tibet-Nepal. J Struct Geol 32: 900-919

LAW RD (2010) Moine thrust zone mylonites at the stack of Glencoul II: results of vorticity analyses and their tectonic significance. In: LAW RD, Butler RWH, Holdsworth R, Krabbendam M, Strachan R (eds) Continental Tectonics and Mountain Building. Geological Society London Special Publications 335: 359-381

Law RD (2014) Deformation thermometry based on quartz c-axis fabrics and recrystallization microstructures: a review. J Struct Geol 66: 129-161

Law RD, SEarle MP, Simpson RL (2004) Strain deformation temperatures and vorticity of flow at the top of the Greater Himalayan Slab, Everest Massif, Tibet. J Geol Soc, London 161: 305-320

Law RD, Stahr DW, Francsis M, Ashley KT, Grasemann B, Aнmad T (2013) Deformation temperatures and flow vorticities near the base of the Greater Himalayan Series, Sutlej Valley and Shimla Klippe, NW India. J Struct Geol 54: 21-53

LisLe RJ (1985) Geological Strain Analysis: A Manual for the $\mathrm{R}_{\mathrm{f}} / \Phi$ Method. Pergamon Press, New York, pp 1-99

Lloyd GE, Freeman B (1994) Dynamic recrystallization of quartz under greenschist conditions. J Struct Geol 16: 867-881

Marques FO, Coelho S (2003) 2-D shape preferred orientations of rigid particles in transtensional viscous flow. J Struct Geol 25: 841-854

Marques FO, Schmid DW, Anderson TB (2007) Applications of inclusion behaviour models to a major shear zone system: the Nordfjore-Sogen detachment zone in western Norway. J Struct Geol 29: 1622-1631

Masuda T, Michibayashi K, Ohata H (1995) Shape preferred orientation of rigid particles in a viscous matrix; reevaluation to determine parameters of ductile deformation. J Struct Geol 17: 115-129
McQuarrie N, Stock JM, Verdel C, Wernicke BP (2003) Cenozoic evolution of Neotethys and implications for the causes of plate motions. Geophys Res Lett 30: 20-36

Means WD (1994) Rotational quantities in homogeneous flow and development of small-scale structures. J Struct Geol 16: 437-446

Mohajuel M, Fergusson C (2000) Dextral transpression in Late Cretaceous continental collision, Sanandaj-Sirjan Zone, western Iran. J Struct Geol 22: 1125-1139

Mouthereau F (2011) Timing of uplift in the Zagros belt/ Iranian Plateau and accommodation of late Cenozoic Arabia-Eurasia convergence. In: GrasEMANN B, SiMPSON G (eds) Geodynamic Evolution of the Zagros. Geol Mag 148: 726-738

MukherJee S (2011) Mineral Fish: their morphological classification, usefulness as shear sense indicators and genesis. Int J Earth Sci 100: 1303-1314

MuKherJeE S (2012) Simple shear is not so simple! Kinematics and shear senses in Newtonian viscous simple shear zones. Geol Mag 149: 819-826

MukHerJee S (2013) Deformation Microstructures in Rocks. Springer, Berlin, pp 1-111

Mukherjee S (2014) Atlas of Shear Zone Structures in Meso-scale. Springer, Berlin, pp 1-128

MukherJeE S (2015) Atlas of Structural Geology. Elsevier, Amsterdam, pp 1-200

MukHerJeE S, Biswas R (2014) Kinematics of horizontal simple shear zones of concentric arcs (Taylor-Couette flow) with incompressible Newtonian rheology. Int J Earth Sci 103: 597-602

Mukherjee S, Koyi HA (2010) Higher Himalayan Shear Zone, Zanskar Indian Himalaya: microstructural studies and extrusion mechanism by a combination of simple shear and channel flow. Int J Earth Sci 99: 1083-1110

Olsen TS, Kohlstedt DL (1985) Natural deformation and recrystallization of some intermediate plagioclase feldspars. Tectonophysics 111: 107-131

PAsschier CW (1987) Stable positions of rigid objects in non-coaxial flow: a study in vorticity analysis. J Struct Geol 9: 679-690

PASSCHIER CW (1988) Analysis of deformation paths in shear zones. Geol Rundsch 77: 309-318

Passchier CW, Trouw RAJ (2005) Microtectonics. Springer, Berlin, pp 1-366

Passchier CW, Brink CE, Bons PD, Sokoutis D (1993) $\sigma$ objects as a gauge for stress sensitivity of strain rate in mylonites. Earth Planet Sci Lett 120: 239-245

Poli L, Oliver GJH (2001) Constrictional deformation in the Central Zone of the Damara Orogen, Namibia. J Afr Earth Sci 33: 303-321

Price RA (1973) Large-scale gravitational flow of supracrustal rocks, southern Canadian Rockies. In: DE JONG KA, Scholten R (eds) Gravity and Tectonics. Wiley, New York, pp 491-502 
Price RA, Mountjoy EW (1970) Geologic structures of the Canadian Rocky Mountains between the Bow and Athabasca rivers - a progress report. In: WHEELER JO (ed) Structure of the Southern Canadian Cordillera. Association of Canada Special Publications 6: 7-25

Prokešová R, Plašienka D, Milovský R (2012) Structural pattern and emplacement mechanisms of the Križna cover nappe (Central Western Carpathians). Geol Carpath 63: 13-32

PRYER LL (1993) Microstructures in feldspars from a major crustal thrust zone: the Grenville Front Ontario Canada. J Struct Geol 15: 21-36

RAMBERG H (1980) Diapirism and gravity collapse in the Scandinavian Caledonides. J Geol Soc, London 137: 261-270

RAMSAY JG (1980) Shear zone geometry: a review. J Struct Geol 2: 83-99

Ramsay JG, Huber MI (1983) The Techniques of Modern Structural Geology, vol. 1. Academic Press, London, pp 1-307

Regenauer-Lieb K, Yuen DA (2003) Modeling shear zones in geological and planetary sciences: solid- and fluid-thermal-mechanical approaches. Earth Sci Rev 63: 295-349

Rey P, Vanderhaeghe O, Teyssier C (2001) Gravitational collapse of the continental crust: definition, regimes and modes. Tectonophysics 342: 435-449

SAMANI B (2013) Quartz c-axis evidence for deformation characteristics in the Sanandaj-Sirjan Metamorphic Belt, Iran. J Afr Earth Sci 81: 28-34

SARKARINEJAD K (1999) Tectonic finite strain analysis using Ghouri deformed conglomerate, Neyriz area, southwestern Iran. Ir J Sci Techn 23: 352-363

Sarkarinejad K, Azizi A (2008) Slip partitioning and inclined dextral transpression along the Zagros Thrust System, Iran. J Struct Geol 30: 116-136

Sarkarinejad K, Ghanbarian MA (2014) The Zagros hinterland fold-and-thrust belt in-sequence thrusting, Iran. J Asian Earth Sci 85: 66-79

Sarkarinejad K, Faghih A, Grasemann B (2008) Transpressional deformations within the Sanandaj-Sirjan Metamorphic Belt (Zagros Mountains, Iran). J Struct Geol 30: 818-826

Sheiknoleslami Mr, Pique A Mobayen P, Sabzehei M, BelLON H, Hashem EMami M (2008) Tectono-metamorphic evolution of the Neyriz Metamorphic Complex, QuriKor-e-Sefid area (Sanandaj-Sirjan Zone, SW Iran). J Asian Earth Sci 31: 504-521

Shigematsu N (1999) Dynamic recrystallization in deformed plagioclase during progressive shear deformation. Tectonophysics 305: 437-452

SimPSon C (1985) Deformation of granitic rocks across the brittle-ductile transition. J Struct Geol 7: 503-511

SimPSON C (1998) Variation in relative recrystallized grain sizes of quartz and feldspar with deformation temperature
In: Snoke AW, Tullus J, Todd VR (eds) Fault-Related Rocks: A Photographic Atlas. Princeton University Press, Princeton, pp 256-259

Simpson C, De Paor DG (1993) Strain and kinematic analysis in general shear zones. J Struct Geol 15: 1-20

Simpson C, WinTsch RP (1989) Evidence for deformationinduced K-feldspar replacement by myrmekite. J Metamorph Geol 7: 261-275

Stipp M, Stünitz H, Heilbronner R, Schmid SM (2002a) The eastern Tonale fault zone: a 'natural laboratory' for crystal plastic deformation of quartz over a temperature range from 250 to $700^{\circ} \mathrm{C}$. J Struct Geol 24: 1861-1884

Stipp M, Stünitz H, Heilbronner R, Schmid SM (2002b) Dynamic recrystallization of quartz: correlation between natural and experimental conditions. In: De Meer $S$, Drury Mr, De Bresser JHP, Pennock GM (eds) Deformation Mechanisms, Rheology and Tectonics: Current Status and Future Perspectives. Geological Society London Special Publications 200: 171-190

STÖCKLIN J (1968) Structural history and tectonics of Iran: a review: AAPG Bull 52: 1229-1258

SulLIVAN WA (2008) Significance of transport-parallel strain variations in part of the Raft River shear zone, Raft River Mountains, Utah, USA. J Struct Geol 30: 138-158

Thigpen RJ, Law RD, Lloyd GE, Brown SJ (2010) Deformation temperatures vorticity of flow and strain in the Moine thrust zone and Moine nappe: reassessing the tectonic evolution of the Scandian foreland-hinterland transition zone. J Struct Geol 32: 920-940

TulLis J (2002) Deformation of granitic rocks: experimental studies and natural examples. In: KARATO S WenK $\mathrm{H}$ (eds) Plastic Deformation of Minerals and Rocks. Mineralogical Society of America and Geochemical Society Reviews in Mineralogy and Geochemistry 51: 51-95

Tuluis J, Yund RA (1985) Dynamic recrystallization of feldspar: a mechanism for ductile shear zone formation. Geology 13: 238-241

Tuluis J, Yund RA (1992) The brittle-ductile transition in feldspar aggregates: an experimental study. In: Evans B, Wong TF (eds) Fault Mechanics and Transport Properties in Rocks. Academic Press, New York, pp 89-118

Van Bemmelen RW (1960) New views on East-Alpine orogenesis. $21^{\text {st }}$ International Geological Congress, Copenhagen 18, 99-116

Vauchez A, Tommasi A (2003) Wrench faults down to the asthenosphere: geological and geophysical evidence and thermo-mechanical effects. In: STORTI F (eds) Intraplate Strike-slip Deformation Belts. Geological Society London Special Publications 210: 15-34

Vidal JL, Kubin L, Debat P, Soula JL (1980) Deformation and dynamic recrystallization of K-feldspar augen in orthogneiss from Montagne Noire, Occitania, southern France. Lithos 13: 247-244 
WALLIS SR (1992) Vorticity analysis in a metachert from the Sanbagawa Belt, SW Japan. J Struct Geol 14: 271-280

WaLlis SR (1995) Vorticity analysis and recognition of ductile extension in the Sanbagawa Belt, SW Japan. J Struct Geol 17: 1077-1093

Wallis SR, Platt JP, Knott SD (1993) Recognition of syn-convergence extension in accretionary wedges with examples from the Calabrian arc and the eastern Alps. Amer J Sci 293: 463-495

White SH, Burrows SE, Carreras J, Shaw ND, Humphreys FJ (1980) On mylonites in ductile shear zones. J Struct Geol 2: 175-188

Williams PF, JiANG D (2005) An investigation of lower crustal deformation: evidence for channel flow and its implications for tectonics and structural studies. J Struct Geol 27: 1486-1504

WundERLICH HG (1953) Bau und Entwicklung des Harznordrandes bei Bad Harzburg. Geol Rundsch 41: 200-223

Xypolias P (2009) Some new aspects of kinematic vorticity analysis in naturally deformed quartzites. J Struct Geol 31: 3-10
Xypolias P, Kokkalas S (2006) Heterogeneous ductile deformation along a mid-crustal extruding shear zone: an example from the External Hellenides (Greece) In: LAW RD, Searle MP, Godin L (eds) Channel Flow, Ductile Extrusion and Exhumation in Continental Collision Zones. Geological Society London Special Publications 268: 497-516

Xypolias P, Koukouvelas IK (2001) Kinematic vorticity and strain patterns associated with ductile extrusion in the Chelmos shear zone (External Hellenides, Greece). Tectonophysics 338: 59-77

Xypolias P, Chatzaras V, Koukouvelas IK (2007) Strain gradients in zones of ductile thrusting: insights from the External Hellenides. J Struct Geol 29: 1522-1537

Xypolias P, Spanos D, Chatzaras V, Kokmalas S, KouKOUVElas L (2010) Vorticity of flow in ductile thrust zones: examples from the Attico-Cycladic Massif (Internal Hellenides, Greece). In: LAw R, Butler R, HoldSWORTH B, KrabBEndam M, Strachan R (eds) Continental Tectonics and Mountain Building. Geological Society London Special Publications 335: 687-714 